\title{
Management of overexploited Dhaka City aquifer, Bangladesh
}

\author{
*M. Qumrul Hassan ${ }^{1}$ and Anwar Zahid ${ }^{1,2}$ \\ ${ }^{\prime}$ Department of Geology, Faculty of Earth and Environmental Sciences, \\ University of Dhaka, Dhaka 1000, Bangladesh \\ ${ }^{2}$ Ground Water Hydrology, Bangladesh Water Development Board, Dhaka 1205, Bangladesh \\ (*E-mail: mqhassan2009@gmail.com)
}

\begin{abstract}
The Dhaka City is the capital of Bangladesh with a total population of over 14 millions and about $2.3 \mathrm{Mm}^{3}$ of water required to fulfill the daily demand of Dhaka City dwellers. Amongst this demand, about $2.0 \mathrm{Mm}^{3}$ of groundwater have been withdrawing from the Plio-Pleistocene Dupi Tila Formation, presently serves as the Main Aquifer of the area. About 563 tube-wells belonging to Dhaka Water Supply and Sewerage Authority (DWASA) and more than 2000 private different depths and levels of tube-wells have been withdrawing groundwater from this aquifer at the rate of $2-3$ cusec and 1-3 cusec, respectively. The uncontrolled abstraction groundwater creates management problem of water resources in the city.

The rechargeable areas are being reduced gradually due to un-planned urbanization. Thus, the process of natural water recharge to the aquifer has not kept pace since three decades and the water withdrawal from the aquifer further causing decline in water table in upper aquifer. Private owned tube-wells and 4 surface water treatment plants of DWASA meet up partial fulfillment. Compare to the over exploitation of groundwater, the renewable recharge of aquifer is very negligible. As mentioned that the rechargeable surface area is decreasing day by day due to construction of buildings, roads and concrete pavements, etc. and besides, the subsurface 7 to $25 \mathrm{~m}$ thick compact upper clay layers, which is about $40 \mathrm{~m}$ in the eastern part of the city, is also responsible for very low vertical recharge. As a result, the lowering trend of groundwater level since last 38 years is from 20 to $30 \mathrm{~m}$ in upper aquifer with an average decline of more than $1.0 \mathrm{~m}$ per year. The recent investigation shows that water pollution is also an additional great problem in the city area. Municipal liquid and solid wastes and the local industrial wastewater are the major components that are playing active role in the contamination processes.

Under the present abstraction scenario the groundwater level would continue to decline at a rate of $3.0 \mathrm{~m} / \mathrm{year}$ in the densely populated areas. This continuous lowering of water table has already caused problems to abstract water from upper or $1^{\text {st }}$ exploited aquifer and demands the necessity to explore deeper aquifers. In this context, consideration on the Dhaka Water Budget (DWB) is an important tool for the better supply of water to city dwellers. This DWB includes surface-water, groundwater, rain water harvesting, etc. and take care of groundwater aquifer management systems, and also a guide-line for safe water, are needed for sustainable use of the limited resources to avoid further shortage of water in the deeper aquifers of the Dhaka City.
\end{abstract}

Keywords: Overexploitation, water level declination, sustainable management, Dhaka water budget

Received: 15 January 2011

\section{INTRODUCTION}

Water supply in Dhaka City has been managed since more than 100 years ago where systematic groundwater development started in 1949 (Chowdhury and Faruqui 1991; Ahmed et al. 1998). Considering the total population of over 14 million, presently more than $2.3 \mathrm{Mm}^{3}$ of water is required every day to fulfill the municipal demand of Dhaka City. Dhaka is dependent mainly on groundwater resources of fluvio-deltaic Plio-Pleistocene Dupi Tila aquifer that provides about $85 \%$ of total water supply (DWASA 2006). Groundwater is the first choice for the city dwellers as it is superior in quality and easy to develop. Amongst the demand about $2.0 \mathrm{Mm}^{3}$ is withdrawn by about 563 DWASA (Dhaka revision accepted: 15 July 2011

Water Supply and Sewerage Authority) tubewells (Fig. 1) and delivered to the inhabitants by $2500 \mathrm{~km}$ long pipeline network, where system loss is assumed more than $25 \%$. It is estimated that the volume extracted by more than 2000 private deep tubewells in the city area may be more than $50 \%$ of the DWASA withdrawal. Compare to the over exploitation of groundwater, the renewable recharge to aquifer is very negligible. Natural water recharge to aquifer cannot keep pace with the water withdrawal since more than three decades, causing declination of water table. The average annual rate of declination in different parts of Dhaka City is 0.17 to 0.6 $\mathrm{m}$ from 1970 to $1980,0.15$ to $0.69 \mathrm{~m}$ from 1980 to 1990 , 0.56 to $2.26 \mathrm{~m}$ from 1990 to 2000 and 1.24 to maximum of $3.5 \mathrm{~m}$ since 2000 . The lowering trend of groundwater level 


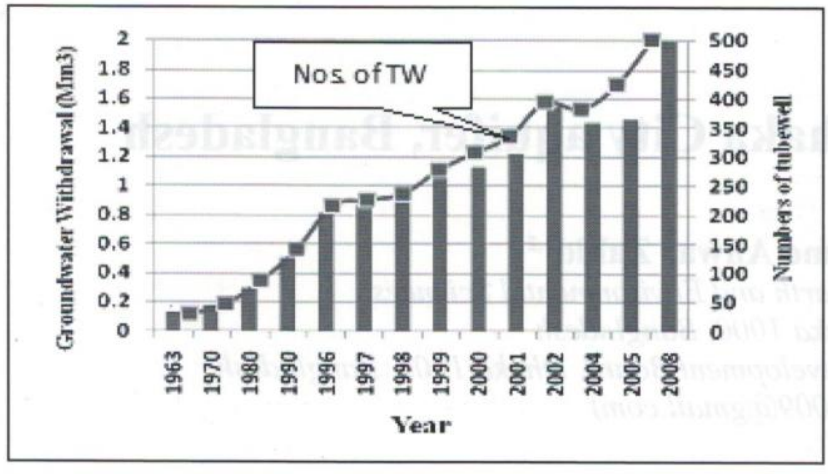

Fig. 1: Rapid increase of groundwater abstraction and numbers of DWASA tubewells (DWASA 2006)

since last 15 years in many locations is $3.0 \mathrm{~m} /$ year without replenishing water table in the city area. The river Buriganga surrounds the city to the south and west and Lakhya and Balu to the east. The convergence of the Turag and Bansi rivers limits the northern boundary. Differences of the river water and groundwater levels support the scope of horizontal inflow but the siltation of river beds are not favorable for the inflow. Hence the contribution to the aquifer from the adjoining rivers is also not remarkable.

Facing problem in the main part of the Dupi Tila aquifer (125-150 m depth), tubewell depth is now extended to 300 $320 \mathrm{~m}$, generally below aquitard. The future daily demand of water is estimated as 3.05 and $4.42 \mathrm{Mm}^{3}$ for the year 2015 and 2025 respectively considering current trend of growing population (DWASA 2006). Overexploitation of groundwater beneath many large cities in the world has resulted environmental hazards including water quality problems (Eisen and Anderson 1980, Prasad 1994, Ahmed et al. 1998, Ford and Tellam 1994). If the groundwater table declination continues in such an alarming rate, this will create huge pressure on water storage and may invite large ecological and environmental hazards.

\section{MANAGEMENT OF WATER SUPPLY: PAST, PRESENT AND FUTURE}

In 1874 the Chadnighat Water Works were constructed on the River Buriganga to provide treated river water for Dhaka. Department of Public Health Engineering (DPHE) drilled the first borehole in Dhaka in 1949, initiating groundwater development for public water supply. By the 1960 s, groundwater became the principal source for city water supply. DWASA started its activities in 1963 with the mandate to provide water supply, disposal of domestic and industrial sewerage, storm water drainage and solid waste management. In 1966 groundwater abstraction had reached $0.08 \mathrm{Mm}^{3} /$ day, with surface water providing less than $0.03 \mathrm{Mm}^{3} /$ day. After independence in 1971, the city had a population of less than two million and groundwater abstraction was about $0.14 \mathrm{Mm}^{3} /$ day. DWASA installed 150 tubewells, up to $180 \mathrm{~m}$ deep, by 1992 and were yielding a total of $0.47 \mathrm{Mm}^{3} /$ day. In late 2000 , DWASA was pumping

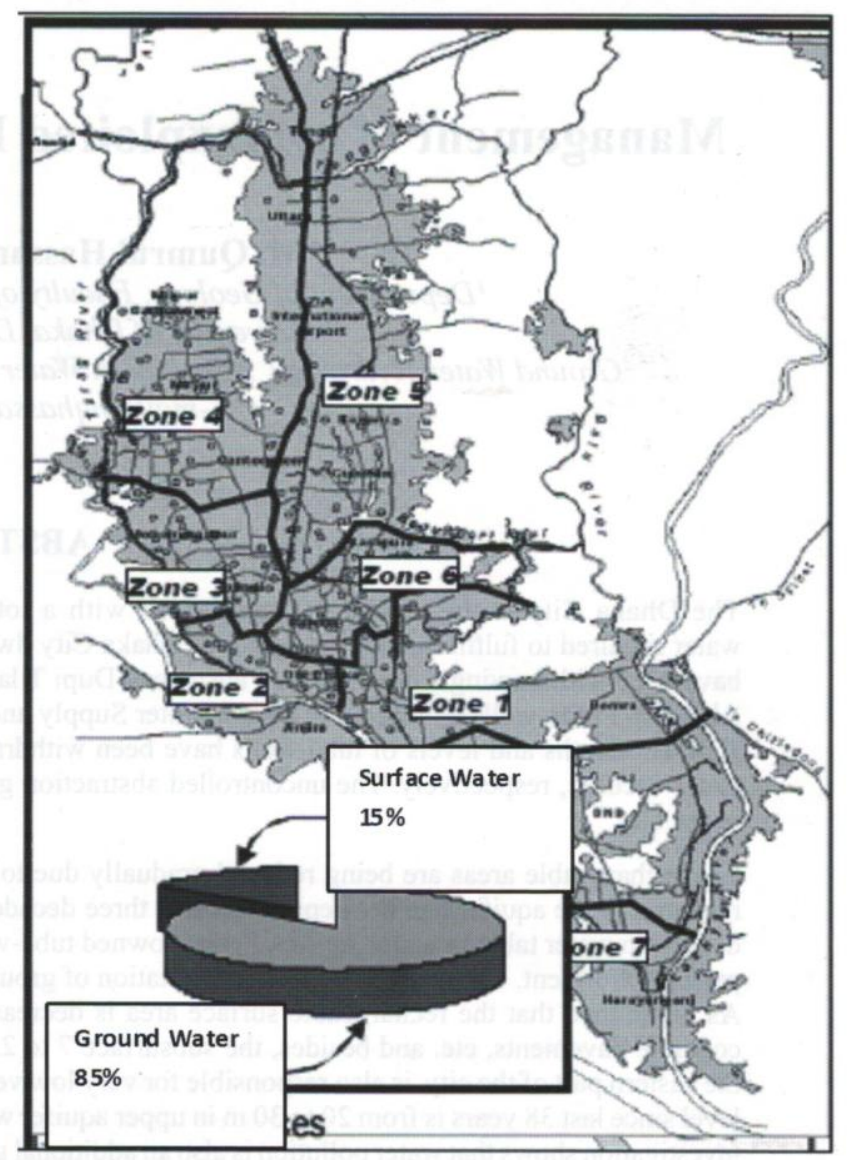

Fig. 2: DWASA water supply zones (2006)

approximately $1.1 \mathrm{Mm}^{3}$ daily from a total of more than 330 tubewells (Morris et al 2003). DWASA divides the metropolitan city into 7 zones (Fig. 2) of water supply.

\section{MATERIALS AND METHODS}

Existing borehole lithologic logs of Bangladesh Water Development Board (BWDB) and Bangladesh University of Engineering and Technology (BUET), groundwater table data of BWDB and Dhaka University and groundwater development information from DWASA are used in this paper to asses the aquifer system and trend of groundwater exploration from Dhaka aquifer for Dhaka City water supply.

\section{Hydrogeology and aquifer system of Dhaka City}

Dhaka City lies on the central portion of the platform flank and surrounded by Chandpur-Barishal Gravity High in the east and south and by Faridpur Trough to the west. Madhupur Forest Tract borders on the north and northwest. NW-SE trending fault along the Buriganga river, N-S trending Baunia fault in the west and the Demra fault in the eastern outskirts has been identified around the city (Ahmed et al. 1998). Pleistocene alluvium occupies the dissected uplands, and alluvium of recent river-borne deposits covers the low lying flood plains of the city area. Madhupur Clay 
of the Pleistocene age, characterized by reddish plastic clay with silt and very fine sand overlies the Dupi Tila Formation of the Pliocene age, that forms the main aquifers. Dupi Tila is composed of medium to coarse yellowish brown sand and occasional gravel. The incised channels and depressions are floored by recent alluvial floodplain deposits. The land surface of the city is covered by 7 to $25 \mathrm{~m}$ thick clay to silty clay formation that is 30 to $45 \mathrm{~m}$ in the eastern side. The upper aquifer system ( $1^{\text {st }}$ aquifer) can be shown as (Fig. 3 ); the upper formation that consists of very fine to fine sand, in places associated with traces of silt and extends down to the depth of 30 to $90 \mathrm{~m}$; the middle part is composed of fine to medium sandy layer in places associated with coarse sand at depth, extends down to drilling depth of 100 to $240 \mathrm{~m}$ with thickness ranges from 50 to more than $200 \mathrm{~m}$; and the lower part consists of medium to coarse sand formation with gravel, extends down to the depth of 95 to $260 \mathrm{~m}$ with thickness ranges between 20 and $40 \mathrm{~m}$. Deep logs reveal the presence of deep $\left(2^{\text {nd }}\right)$ aquifer, overlain by clay aquitard of few meters, consist of gray very fine and fine sand with medium sand at the depth of 150 to $300 \mathrm{~m}$ from the land surface.

The thickness of upper clay ranges from 15 to $18 \mathrm{~m}$ at Mirpur area, north-western part of the city, which is very compact in nature. At Mohammadpur area, the upper silty clay layer ranges between 10 and $25 \mathrm{~m}$ from land surface. At Dhanmandi area, south-western part of the city, the upper clay of $9 \mathrm{~m}$ thickness is observed. At Lalbagh area, southern part of the city, the thickness of upper silty clay layer ranges between 7 and $9 \mathrm{~m}$ from the surface. At Tejgaon area, central part of the city, stiff to hard clay layer of 9 to $12 \mathrm{~m}$ thick is detected at the borelogs located about $1.5 \mathrm{~km}$ from each other. At Sabujbagh area, thick silty clay layer of 40 to 45 $\mathrm{m}$ from the surface characterize the subsurface lithology. At the eastern part of Dhaka City, this unit is exposed at few places.

The Madhupur Clay mainly consists of kaolinite (26.79-53.33\%) and illite (13.73-33.04\%) with very small amount of illite-smectite (2.11-12.94\%) down to $5 \mathrm{~m}$ depth (Nairuzzaman et al. 2000). The intrinsic permeability and hydraulic conductivity of these clay and silty clay varies from $10^{-6}$ to $10^{-3}$ darcys and $10^{-9}$ to $10^{-6} \mathrm{~cm} / \mathrm{s}$ respectively (Fetter 1994). The vertical permeability varies from $6.5 \times 10^{-4}$ to $1.5 \times 10^{-2} \mathrm{~m} /$ day (DWASA 1991) that can neither yield to wells nor transmit appreciable water to the aquifer below. The permeability of the main portion of Dupi Tila aquifer, from where water is abstracted for Dhaka City, is 25 to 46 meter/ day for Madhupur Tract aquifers and 50 to 90 meter/day for Recent Floodplain aquifers (DWASA 1999). The moisture content and plastic limit results show that Madhupur Clay is normally consolidated. The clay is normal to active and has intermediate to high plasticity. The clay is very low to highly compressible at different locations.

\section{Recharge to aquifers}

The recharge to the $1^{\text {st }}$ aquifer occurs mainly by the horizontal inflow from the surrounding areas and a portion from the vertical percolation of rain and floodwater. The recharge to the Dupi Tila aquifer is by topographically driven vertical leakage through the Madhupur Clay. The rechargeable surface area of the city is decreasing due to increasing urbanization. The rechargeable surface area is decreasing day by day due to construction of buildings, roads and concrete pavements i.e. unplanned urbanization. Besides, compact upper clay layer in the subsurface obstructs vertical recharge though the average annual rainfall in the city area is about $1800 \mathrm{~mm}$. Lowering of water level increases the length of flow paths that in turn develops the time constraint of recharge that also reduces vertical hydraulic conductivity due to drying of pores (Morris et al. 2003). The contribution to the aquifer system from rivers seems to be limited which is generally indicated by the differences between the river stages and the groundwater levels. However, the Buriganga allows recharge to the aquifer. Under the present conditions, the peripheral rivers act as sources of recharge where the Dupi Tila sands are exposed along the riverbeds (Ahmed et al. 1998). Leakage from water distribution lines and sewage system is also adding water to the aquifer but these are inadequate in fulfilling the loss of natural recharge. A long aquifer corridor exists between Brahmaputra-Jamuna fault line and Madhupur tract which may be the main course of

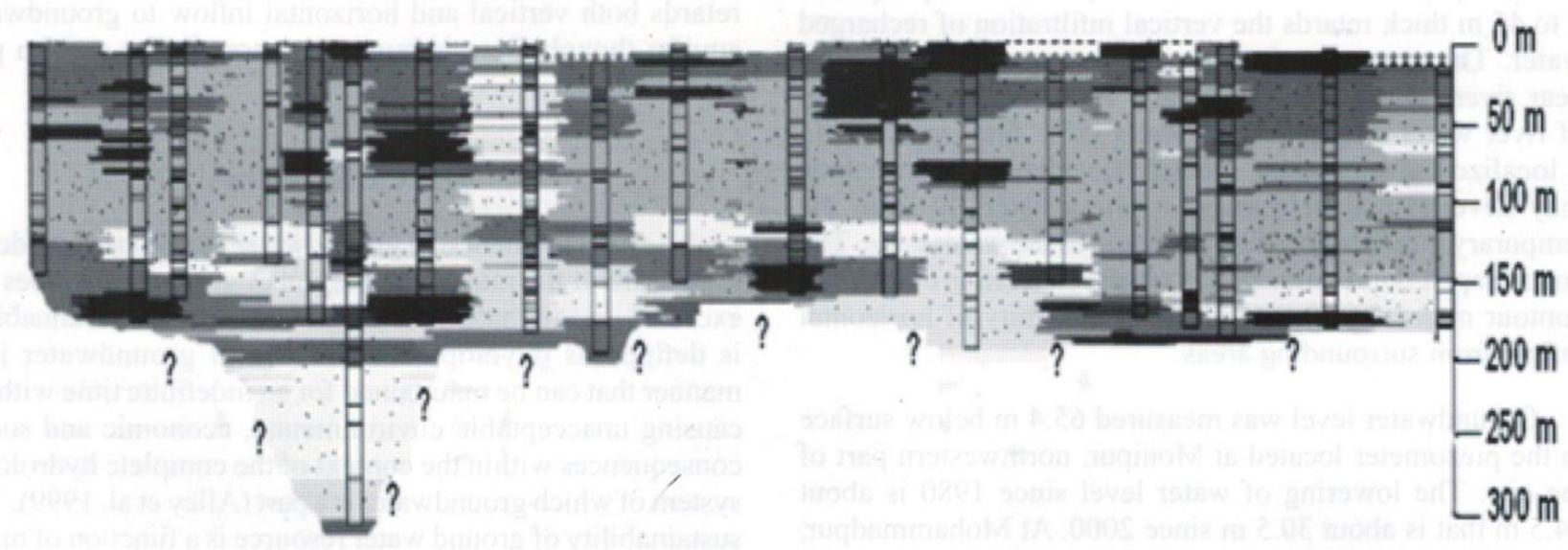

Fig. 3: Aquifer system from Northwest to Southeast of Dhaka City 


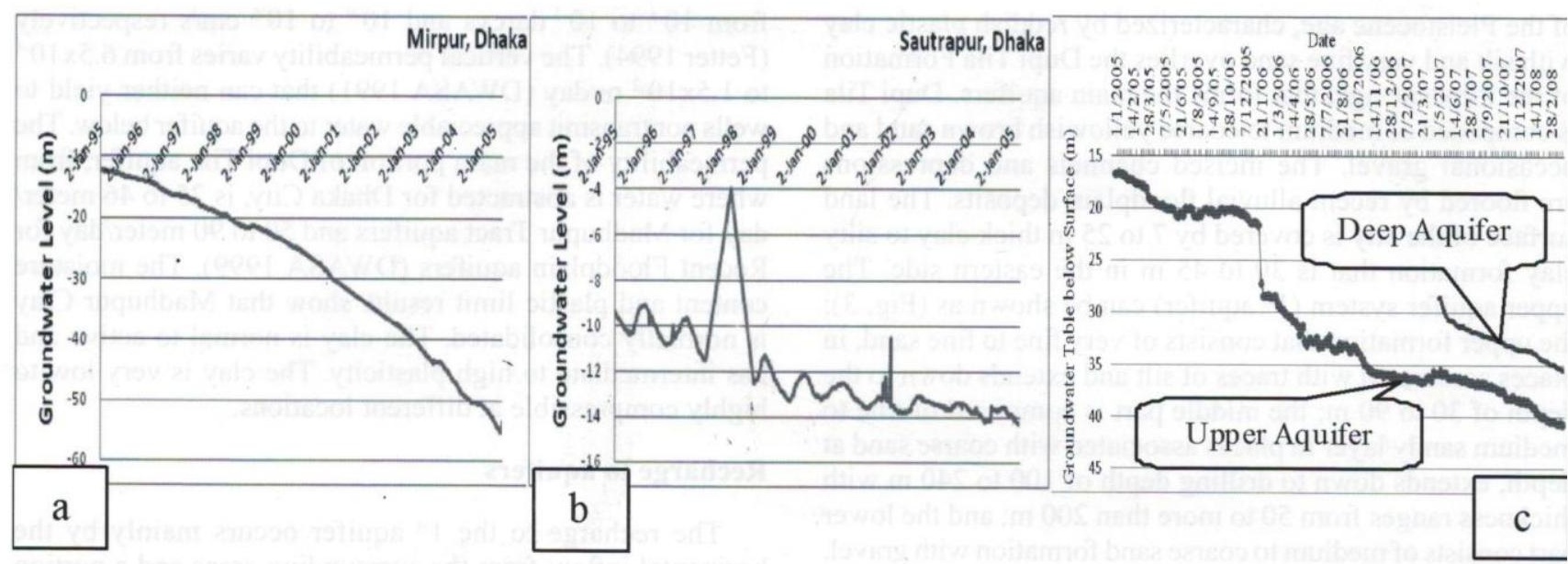

Fig. 4: Declining trend of groundwater level in Dhaka City: (a) With continuous lowering; (b) Continuous lowering with litt fluctuation and (c) Groundwater declining trend of upper and deep aquifers.

long distant recharge channel for deeper aquifer system. Hence the mechanism of groundwater recharge of Dhaka City has not yet been well understood and need to be explored.

\section{Declining trend of groundwater level}

Groundwater level beneath the Dhaka City has started to decline since three decades when rapid urbanization in city resulted into higher water demand. In the period of 19651980, water level decline to about 3-9 m, being maximum at Motijheel and minimum at Banani area. At that time the rate of decline was $0.3-0.5 \mathrm{~m} /$ year. The maximum depth to water table in the central part of Dhaka City i.e. Tejgaon area, is about $67.0 \mathrm{~m}$ below land surface that is about 65.4 $\mathrm{m}$ at Mirpur and 20 to $34 \mathrm{~m}$ at Mohammadpur, Dhanmandi, Sutrapur areas close to the river periphery. This continuous decline of water level with little (Fig. 4b) or even no fluctuation (Fig. 4a) is typical of overexploited aquifers. The thickness of the unsaturated zone is an important factor for water table recharge. Where the unsaturated zone is thinner, recharge can reach the water table faster and for Dhaka aquifer the surfacial semi-impervious clay layer of 7 to $45 \mathrm{~m}$ thick retards the vertical infiltration of recharged water. The unsaturated zone can be expected as thinner near rivers Buriganga, Turag and Balu, where infiltration of river water may reach the water table first, resulting in a localized groundwater mound. Localized flow systems may develop that help water to move laterally from the temporary groundwater mounds towards the water table. The cone shaped depression that is observed from groundwater contour map (Fig. 5), creates an opportunity of horizontal inflow from surrounding areas.

Groundwater level was measured $65.4 \mathrm{~m}$ below surface in the piezometer located at Monipur, northwestern part of the city. The lowering of water level since 1980 is about $54.5 \mathrm{~m}$ that is about $30.5 \mathrm{~m}$ since 2000 . At Mohammadpur, the declination of groundwater table is recorded about 30 $\mathrm{m}$ since 1980 and is $20 \mathrm{~m}$ since 2000 . Infiltrated river water from western boundary may also allow recharge to aquife The water table in the piezometer at Dhanmandi is measure as $33.7 \mathrm{~m}$ that is declined about $10.5 \mathrm{~m}$ since 2000 . Th depth to water table and annual declination is less compar to central and eastern part, though hundreds of tubewell are operated by tannery industries in this area that indicate lateral inflow of water from nearby Buriganga-Turag rivers The water table is measured $20.9 \mathrm{~m}$ from ground surfac in the Sutrapur area. The direct recharge of water fron Buriganga river is contributing a portion to the aquifer bu scope of vertical recharge is less due to dense urbanizatio (Ahmed et al. 1998). The depth to groundwater table observe at Tejgaon of central Dhaka is recorded $67.0 \mathrm{~m}$ from groun surface that is the maximum compare to water table in othe piezometers. This is due to over exploitation of groundwate by industries at Tejgaon area. The dense urbanization and stif clay layer in the surface retard vertical inflow. The declination of groundwater table is about $45.5 \mathrm{~m}$ since 1990 and $33.5 \mathrm{n}$ since 2000 . The depth to water table observed in piezomete at Sabujbagh is $52.75 \mathrm{~m}$ that is declined about $56 \mathrm{~m}$ sinc 1980 and $10.5 \mathrm{~m}$ since 2000 . Clay layer of higher thicknes retards both vertical and horizontal inflow to groundwate aquifer though there is huge open area in the eastern par till river Balu.

\section{DISCUSSIONS}

The development of a groundwater system is considere to be 'safe' if the rate of abstraction of groundwater does no exceed the rate of natural recharge. Groundwater sustainability is defined as development and use of groundwater in manner that can be maintained for an indefinite time withou causing unacceptable environmental, economic and socia consequences within the context of the complete hydrologi system of which groundwater is a part (Alley et al. 1999). Th sustainability of ground water resource is a function of man factors, including depletion of storage, reduction in strean flow, reduction of recharge area, potential loss of wetland anc 
Table 1: Comparison of DWASA groundwater withdrawal and decline of water table

\begin{tabular}{|l|l|l|l|l|l|l|l|}
\hline Year & 1970 & 1980 & 1990 & 1995 & 2000 & 2005 & 2009 \\
\hline Nos. of Tubewell & 49 & 75 & 130 & 197 & 300 & 423 & 510 \\
\hline Withdrawal $\left(\mathrm{mm}^{3}\right.$ /day) & 0.18 & 0.217 & 0.516 & 0.767 & 1.2 & 1.5 & $>2.0$ \\
\hline Water Table $(\mathrm{m})$ & $0.5-10.5$ & $0.5-9$ & $6-22.5$ & $12.5-32$ & $19-41.5$ & $19-54$ & $21-67$ \\
\hline
\end{tabular}

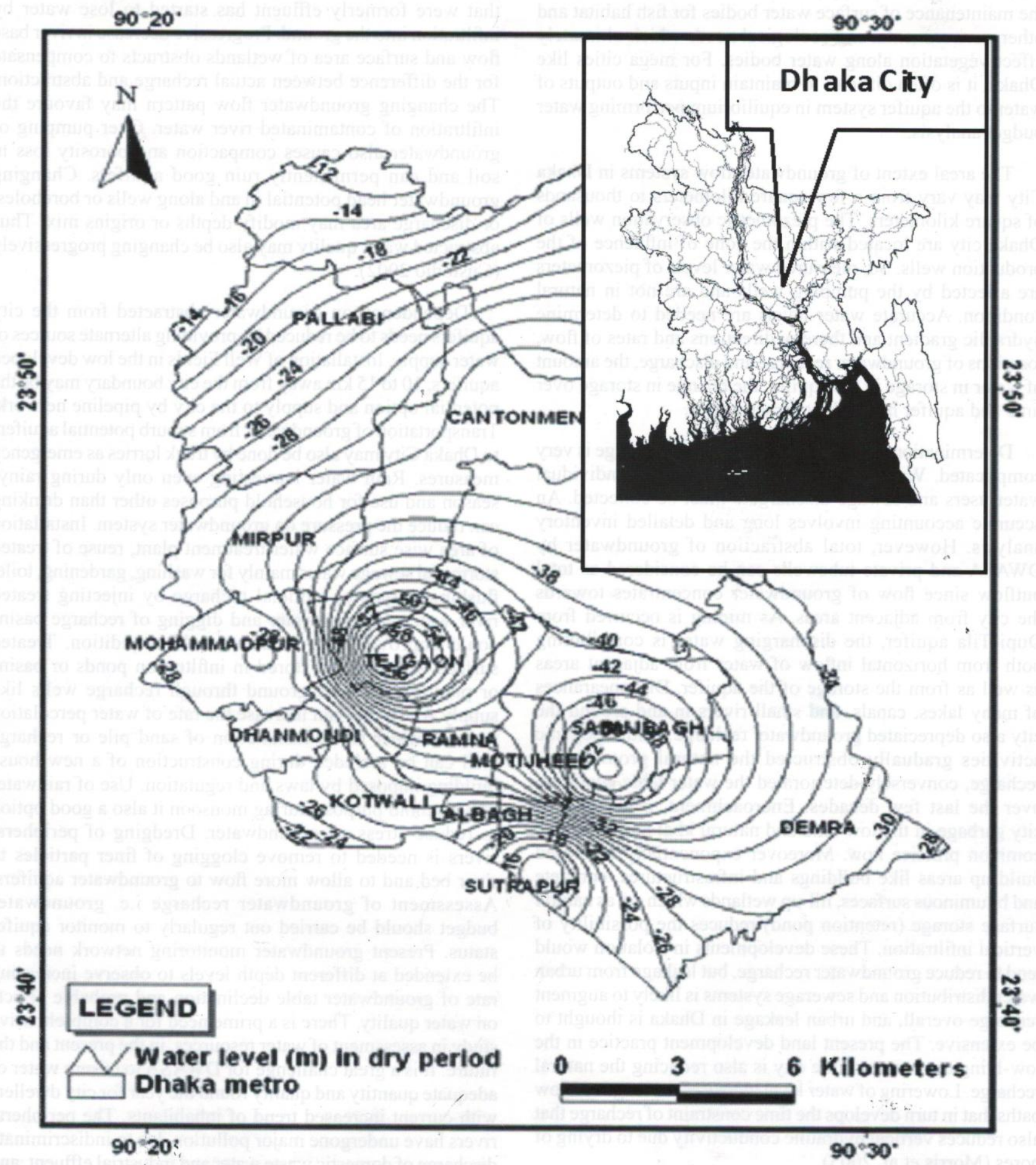

Fig 5: Location map of Dhaka City and groundwater level contour map 
riparian ecosystem. In the Dupi Tila aquifer of Dhaka City, withdrawals of water through hundreds of wells has increased the cone of depression, resulting contribution of water from storage of aquifer and these cones of depression create a complex surface of water table. Hence, the development and management of groundwater is more complicated than that of surface water. Excessive withdrawal of groundwater can affect not only water supply for human consumption but also the maintenance of surface water bodies for fish habitat and other environmental and ecological needs which ultimately affect vegetation along water bodies. For mega cities like Dhaka, it is often difficult to maintain inputs and outputs of water to the aquifer system in equilibrium performing water budget analysis.

The areal extent of groundwater flow systems in Dhaka City may vary from a few square kilometers to thousands of square kilometers. The piezometric observation wells of Dhaka city are located within the zone of influence of the production wells. So, measured water levels of piezometers are affected by the pumping wells and are not in natural condition. Accurate water levels are needed to determine hydraulic gradient and thereby directions and rates of flow, locations of groundwater recharge and discharge, the amount of water in storage in the aquifer, the change in storage over time and aquifer hydraulic characteristics.

Determination of additional groundwater recharge is very complicated. Water use records of hundreds of individual water users and sewage dischargers must be collected. An accurate accounting involves long and detailed inventory analysis. However, total abstraction of groundwater by DWASA and private tubewells can be considered as total outflow since flow of groundwater concentrates towards the city from adjacent areas. As mining is occurred from Dupi Tila aquifer, the discharging water is contributing both from horizontal inflow of water from adjacent areas as well as from the storage of the aquifer. Disappearances of many lakes, canals, and small rivers in and around the city also depreciated groundwater recharge. Anthropogenic activities gradually obstructed the natural groundwater recharge, conversely deteriorated the water table condition over the last few decades. Encroachment, deposition of city garbage in the low land and natural khal has become a common practice now. Moreover exponentially increased build up areas like buildings and infrastructures, concrete and bituminous surfaces, fill-up wetlands which act as natural surface storage (retention pond) reduces the possibility of vertical infiltration. These developments in isolation would tend to reduce groundwater recharge, but leakage from urban water distribution and sewerage systems is likely to augment recharge overall, and urban leakage in Dhaka is thought to be extensive. The present land development practice in the low-lying areas around the city is also reducing the natural recharge. Lowering of water level increases the length of flow paths that in turn develops the time constraint of recharge that also reduces vertical hydraulic conductivity due to drying of pores (Morris et al. 2003).
If the present rate of abstraction, unplanned urbanization and silting of riverbeds continues, lateral inflow of water to groundwater aquifer will reduce and groundwater mining will be aggravated. Lowering of groundwater table leads to an increased cost of development, the early replacement and deepening of wells and pumps, and the need to enlarge energy facilities. Moreover electricity consumption will be higher to lift water from greater depth. Surrounding rivers that were formerly effluent has started to lose water by infiltration into the ground. Progressive decrease in river base flow and surface area of wetlands obstructs to compensate for the difference between actual recharge and abstraction. The changing groundwater flow pattern may favoure the infiltration of contaminated river water. Over pumping of groundwater also causes compaction and porosity loss in soil and can permanently ruin good aquifers. Changing groundwater head potential in and along wells or boreholes, or discharge area may modify depths or origins mix. Thus abstracted water quality may also be changing progressively (Custodio 2002).

Dependency on groundwater abstracted from the city aquifers needs to be reduced by providing alternate sources of water supply. Installation of Well Fields in the low developed aquifers, 10 to $15 \mathrm{~km}$ away from the city boundary may be the potential option and supply to the city by pipeline network. Transportation of groundwater from suburb potential aquifers to Dhaka City may also be done by truck lorries as emergency measures. Rain water harvesting even only during rainyseason and use for household purposes other than drinking can reduce the pressure on groundwater system. Installation of area wise surface water treatment plant, reuse of treated storm and sewage water mainly for washing, gardening, toilet flushing purposes, artificial recharge by injecting treated river water and rain water and digging of recharge basins could improve the groundwater table condition. Treated surface water can be stored in infiltration ponds or basins or pumping into the ground through recharge wells like supply wells, that can increase the rate of water percolation towards water table. Installation of sand pile or recharge well can be included during construction of a new house building imposed by laws and regulation. Use of rainwater in household purpose during monsoon it also a good option to reduce stress on groundwater. Dredging of peripheral rivers is needed to remove clogging of finer particles to river bed and to allow more flow to groundwater aquifers. Assessment of groundwater recharge i.e. groundwater budget should be carried out regularly to monitor aquifer status. Present groundwater monitoring network needs to be extended at different depth levels to observe increasing rate of groundwater table declination and probable effects on water quality. There is a prime need for a comprehensive study in assessment of water resources, in the present and the future. It is a great challenge for DWASA to ensure water of adequate quantity and quality round the year for city dwellers with current increased trend of inhabitants. The peripheral rivers have undergone major pollution due to indiscriminate discharge of domestic waste water and industrial effluent, and 
the groundwater table is rapidly declining due to large scale abstraction. Therefore, groundwater is no longer a viable option for Dhaka city water supply.

Groundwater resources can also be protected reducing the volume of water use. Here, city dweller can play a very important role. A major portion of the total water consumption is going for bathing, flushing toilets, washing clothes and dishes etc. Significant savings can be made from these areas. Repairing leaking faucets, showerheads and toilets, stopping use of running water during teeth brush etc. can save huge water. There are many other things from where every citizen can save water for future generation. With a rapidly growing population, the savings should be much higher in the future. These will reduce stress on declining groundwater table in the city aquifer.

\section{CONCLUSIONS}

Compare to the over exploitation of groundwater in Dhaka City, the renewable recharge to aquifer is very negligible due to various manmade activities. The low laying (natural rechargeable) wet-land are decreasing day to day by expanding unplanned urbanization. Present groundwater level occurs at a depth of 65.0 to $67.0 \mathrm{~m}$ in the central part of the city that is lowered more than $90 \%$ over the last three decades resulting in groundwater mining and decline of the water level by $20-40 \mathrm{~m}$. If this groundwater level declination will continue long-term basis and it will create pressure on water storage and also may invite land-subsidence, ecological and other environmental hazards. To avoid further deterioration in the aquifer condition an urgent appropriate action plan is required without any delay. Dependency on groundwater abstraction from the city aquifers must be reduced by using detailed water management system including the local Water Budget Estimation.

\section{ACKNOWLEDGEMENTS}

The authors express their gratitude to S. D. Shrestha for his helpfull comments and suggestaions for improvemen this manuscript.

\section{REFERENCES}

Ahmed, K. M., Hassan, M. A., Sharif, S. U., and Hossain, K. S., 1998, Effect of urbanization on groundwater regime, Dhaka city, Bangladesh, Jour Geol. Soc. India, v. 52, pp. 229-238.

Alley, W. M., Reilly, T. E., and Franke, O. L., 1999, Sustainibility of Ground-water Resources, U.S. Geological Survey Circular $1186,79 \mathrm{p}$.

Chowdhury, A. M. and Faruqui, M. S., 1991, Physical growth of Dhaka City. In: Dhaka Past, Present and Future, Ed. S. U. Ahmed, The Asiatic Soc., Bangladesh, Dhaka, pp. 43-46.

Custodio, E., 2002, Aquifer overexploitation: what does it mean? Hydrogeology Jour., v. 10, pp. 254-277.

DWASA, 2006, Water Utility Services in Dhaka City: Present and Future. Workshop presentation by Hedayetullah Al-Mamoon, on Partnerships for Improving the Performance of Water Utilities in the Asia and Pacific Region, 25 - 27 July 2006, Bangkok, Thailand.

DWASA, 2003, Present Status of Surface Water and Groundwate Conditions in Dhaka City, Workshop Paper Presented by ATM Ataur Rahman, Managing Director, DWASA.

DWASA, 1999, Dhaka Water Resources Management Program Briefing, v. 2 (2)

DWASA,1991, Dhaka region groundwater and subsidence study, Final Report, v. 2, Water Supply and Sanitation Urgent Expansion Project, Bangladesh.

Eisen, C. and Anderson, M. P., 1980, The effects of urbanization of groundwater quality-A case study, Groundwater, v. 17(5), pp. 456-462.

Fetter, C. W.,1994, Applied Hydrogeology, Prentice hall, 691 p.

Ford, M. and Tellam J. H.,1994, Source, type and extent of inorganic contamination within the Birmingham urban aquifer system, UK, Jour. Hydrology, v. 156. pp. 101-135.

Morris, B. L, Seddique, A. A, and Ahmed, K. M., 2003, Response of the Dupi Tila Aquifer to Intensive Pumping in Dhaka, Bangladesh, Hydrogeology Jour., v. 11, pp. 496-503.

Nairuzzaman, M., Haque, M. E., and Rahman, M. J. J., 2000 Influence of Clay minerals on Consolidation Behavior of Madhupur Clay: A case Study from Some Samples of Greater Dhaka City, Bangladesh Geoscience Jour., v. 6.

Prasad, R. K., 1994, Overexploitation of groundwater associated phenomena and rehabilitation measures. Proc. Regiona Workshop on Environmental Aspects of Groundwater Development, Kurukshetra, India, v.4, pp.1-8.

Zahid, A., Balke, K-D., Hassan, M. Q., and Flegr, M., 2006, Evaluation of aquifer environment under Hazaribagh leather processing zone of Dhaka city. Jour. Environmental Geology, v. 50 (4), pp. $495-504$.

Zahid, A., Hossain, A., Uddin, M. E., and Deeba, F., 2004, Groundwater level declining trend in Dhaka city aquifer. In "Water Resources Management and Development in Dhaka City", eds. Hassan MQ et al, Alumni Association of German Universities in Bangladesh and German Cultural Center (Goethe Institute), Dhaka. pp. 17-31 